\title{
唾液腺ホルモンの活性フラグメントに関する 生理化学的研究
}

\begin{tabular}{clllll}
\multicolumn{8}{c}{ 大阪大学薬学部 } & & \\
青 沼 & 繁, 小 浜 靖 弘, 小 宮 山 豊 \\
& 中 陳 静 男, 山田 康 子
\end{tabular}

The Study of Physiological Chemistry on Active Fragments of the Salivary Gland Hormone

\section{Shigeru AONUMA, Yasuhiro KOHAMA, Yutaka KOMIYAMA, Shizuo NAKAJIN and Yasuko YAMADA}

Faculty of Pharmaceutical Sciences, Osaka University

We previously presented evidence that the salivary gland hormone, parotin, is composed of a subunit which has a molecular weight of 45000 and possesses the biological and immunological activities of parotin. In this paper the isolation of fragments from a tryptic digest of the subunit and their physiological chemistry were investigated to obtain active components of the subunit.

After $2 \mathrm{~g}$ of the subunit were digested with $20 \mathrm{mg}$ of trypsin for 20 hours at $37^{\circ} \mathrm{C}$, the tryptic digest was chromatographed on a Sephadex G-25 column equilibrated with $0.1 \mathrm{M}$ $\mathrm{NH}_{4} \mathrm{HCO}_{3}$. The eluate was fractionated into 9 parts from Fr. A to Fr. I in order of their molecular size. An increasing activity in the rabbit-circulating leucocyte number of the subunit was separated into 4 fractions of Fr. A, B, D and E. Rabbit serum Ca decreased and immunological activities were recovered into only Fr. $\mathrm{H}$ and $\mathrm{Fr}$. A, respectively. Leucocyte increase and immunological activities of $\mathrm{Fr}$. A were concentrated by successive chromatographies with Sephadex G-50 and QAE-Sephadex A-25 column. A purified component, Fr. AA-1, was found to have a molecular weight of 9100 by $15 \%$ polyacrylamide gel electrophoresis in $0.1 \%$ sodium dodecyl sulfate, N-terminal amino acid sequence of Leu-Tyr-IleLeu-Tyr-Phe-Phe-Glx- by combined dansyl-Edman procedure, C-terminal amino acid sequence of -Ile-Val-Leu-Leu-Lys $(\mathrm{OH})$ by carboxypeptidase A + B method and glycopeptide consisting of $6.9 \%$ amino sugar and $7.4 \%$ uronic acid. A Ca decreasing active principle, Fr. H-1, purified from Fr. $\mathrm{H}$ by paper chromatography, was characterized to be pentapeptide of Asp-Tyr-Glu-Trp-Lys $(\mathrm{OH})$. Both Fr. AA-1 and Fr. H-1 were not positioned on N-and C-terminals of the subunit molecule.

Whole - body autoradiographies of the subunit and active components labeled with 第 53 巻 第 7 号 
${ }^{131} \mathrm{I}$ in mice revealed that the subunit and Fr. AA-1 specifically were localized in the bone in addition to the liver, kidney, thyroid, spleen, adrenal and submaxillary gland, but Fr. H-1 did not distribute to the bone.

\section{緒言}

著者らはすでに唾液腺ホルモン活性を有する分子量45,000の parotin-subunit（subunit）を精製，単離し， その化学的諸性質を明らかにするとともに，このものが骨におけるcyclic AMP-adenyl cyclase系を賦活 化し，Ca 代謝調節に関与していることを認め報告した $\left.{ }^{3}, 4\right)$. 本報では subunit より低分子活性フラグメン 卜を得る目的でtrypsin 加水分解を行なって検討し, 家鬼血清 Ca 低下効力 (Ca効力) を示すぺンタペプチ ドと家鬼循環白血球数增加効力（白血球効力）㧍よび subunit と免疫化学的交叉反応を示す糖ぺプチドを分 離することに成功した。さらに活性フラグメントのアミノ酸配列分析および全身オートラジオグラフィーを 行ない知見を得たので報告する。

\section{実 験 方 法}

Subunit：既報 ${ }^{3)}$ に従い調製した。

Trypsin 加水分解物の調製：Subunit $2 \mathrm{~g} を 0.2 \mathrm{M} \mathrm{NH}_{4} \mathrm{HCO}_{3} 200 \mathrm{~m} \ell$ に溶解し, 希アンモニア水で $\mathrm{pH} 8.2$ に

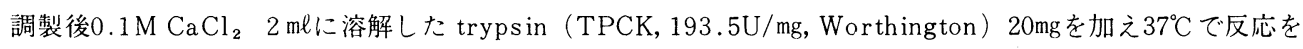
行なった． 5 時間後再び同量の trypsin を加えさらに15時間反応後 $\mathrm{CH}_{3} \mathrm{COOH}$ を加之 $\mathrm{pH} 3.0$ とし 凍結乾燥 した。また限定分解物を調製するために subunit $1 \mathrm{~g}$ を蒸留水 $500 \mathrm{~m} \ell に$ に溶解し， $0.05 \mathrm{~N} \mathrm{NaOH} \mathrm{でpH8.5に}$

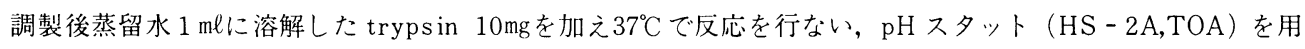
いて175 m moleのカルボン酸が遊離した時点で $\mathrm{CH}_{3} \mathrm{COOH}$ により $\mathrm{pH} 3.0$ とし反応を止め凍結乾燥した。分 解物はカラムクロマトグラフィーおよびペーパークロマトグラフィーを用いて分画, 精裴した. Sephadex

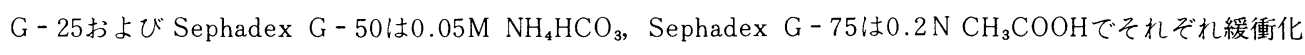
し, またQAE-Sephadex A-25は0.01M tris-HCl buffer (pH8.0) で緩衝化し食塩濃度による gradient elutionを行なった：溶出液は紫外部235，280nmにおける吸光度またはニンヒドリン反応により分析 した。ペーパークロマトグラフィーは東洋沪紙No.50 (60×60cm) を用いn-BuOH:pyridine: $\mathrm{CH}_{3} \mathrm{COOH}: \mathrm{H}_{2} \mathrm{O}$ (15：10：3：12）により展開し、ニンヒドリン反応で検出した。

全身オートラジオグラフィー：正常雄性: $d d Y$ 系マウス（体重25２２ｇ）を用い, 尾静脈より 1 匹当り ${ }^{131} \mathrm{I}$ 標識検体 $6 \sim 7 \mu \mathrm{Ci}$ を投与し, 所定時間後にエーテル麻酔致死せしめ, 直ちに凍結した。ささらに一夜一 $25^{\circ} \mathrm{C}$

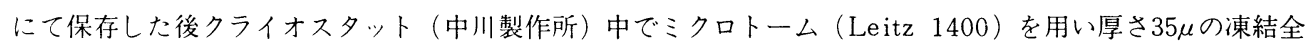
身切片を作製した。切片はクライオスタット中で涷結乾燥した後X線フィルム（Type N) を用いコンタク ト法により冷暗所において露出し全身オートラジオグラムを得た. Subunit および trypsin 加水分解物 (Fr.

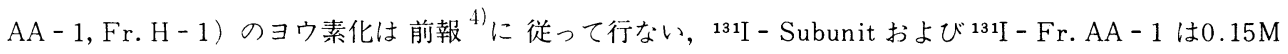
phosphate buffer (pH7.5) で緩衝化したSephadex G－25カラムで, ${ }^{13} \mathrm{I}$ - Fr. H-1は0.2M NaHCO

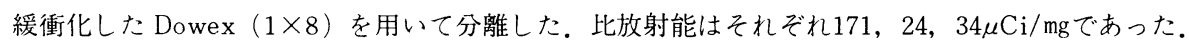

Radioimmunoassay: Subunit $500 \mu \mathrm{g}$ を $200 \mu \mathrm{l}$ の生理食塩水に溶解後等量の Freund complete adjuvant に

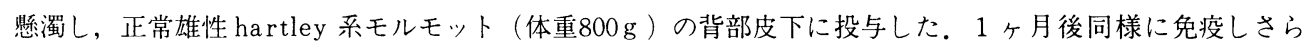
に 1 週間沶いて追加免疫し， 1 週間後に全採血を行ない subunit モルモット抗血清を得た。モルモット $\gamma$ 一 グロブリン家兔抗血清は，モルモット正常血清から硫安分画法により分離した $\gamma$ ーグロブリンを用い, complete adjuvant 法により週 1 回 $2 \mathrm{mg}$ の割合で 4 回体重 $2 \mathrm{~kg}$ の正常雄性家鬼を免疫し, 最終免疫から 1 週間後 
全採血を行ない抗血清を得た。 ${ }^{131} \mathrm{I}$ - Subunitは parotinの場合と同様に調製した. ${ }^{2)}$ 比放射能は $53 \mathrm{mCi} / \mathrm{mg} て ゙$ あった. Radioimmunoassayは ${ }^{13} 1 \mathrm{I}$ - Subunit 約 $20,000 \mathrm{cpm} / 50 \mu \mathrm{l}, 1 / 100$ 希釈の subunit モルモット抗血清 $50 \mu$ l, 試料または標準 subunit $100 \mu \mathrm{l}$ および buffer $100 \mu \mathrm{l}$ を混合し, $4{ }^{\circ} \mathrm{C} に て 3$ 日間反応後, 牛血清 $\gamma$ ーグ ロブリン $50 \mu \mathrm{g} / 100 \mu \mathrm{l}$ および $1 / 2$ 希釈の $\gamma$ ーグロブリン家兔抗血清 $200 \mu \mathrm{l}$ を加之, $4{ }^{\circ} \mathrm{C} に て 1$ 日反応後 3,000 $\mathrm{rpm}, 10$ 分間遠心分離し, 沈殿の放射活性をウエル型シンチレーションカウンターで測定した。結果は添加 した ${ }^{13} 1 \mathrm{I}$ - Subunitに対する沈殿のカウント（B％）で求め, 標準曲線より測定值を算出した。希釈用 bu ffer として0.25\%牛血清アルブミンを含む0.05M phosphate buffer (pH7.5) を用いた。 なお ${ }^{131} \mathrm{I}$ - Subunit が subunit と同様に Ca 効力を有していることを確認している.

アミノ酸配列分析：Dansyl-Edman 法 ${ }^{(6)}$ によりアミノ酸配列分析を行ない $\mathrm{N}$ 末端から順次アミノ酸を検索 した。試薬はすべてアミノ酸配列分析用（和光）を用いた。 Dansylアミノ酸の同定は polyamide layer sheet $\left(5 \times 5 \mathrm{~cm}\right.$, CHENG CHIN TRADING CO.LTD) を用い, Hartley らの方法 ${ }^{8)} に$ 従い, dansyl-Asp, dansyl-Glu を検出した場合には相当する PTHーアミノ酸を調製し Wako gel B - 5F を用いた薄層クロマ トグラフィーにより Asn あるいは Gln の有無を調へた. ${ }^{14)} \mathrm{C}$ 末端アミノ酸配列については Maghuin-Rogis ter らの方法 ${ }^{12)}$ に準じ carboxypeptidase A+B 法により行なった。すなわち10\% LiClで10倍希釈したcarboxypeptidase A ( $21 \mathrm{mg} / \mathrm{m} \ell, 47 \mathrm{U} / \mathrm{mg}$, Sigma) 10 $\mu \mathrm{l}$ およびcarboxypeptidase B $(6 \mathrm{mg} / \mathrm{m} \ell, 101 \mathrm{U} / \mathrm{mg}$, Wo-

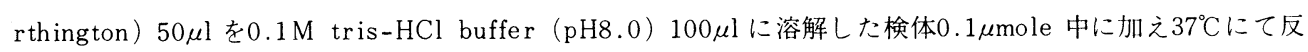
応を行なった，所定時間後一 $25^{\circ} \mathrm{C}$ に凍結することにより反応を停止し，アミノ酸自動分析計により遊離アミ ノ酸の定量を行なった。

生物学的効力, アミノ酸組成, 糖含量の測定およびポリアクリルアミドゲル電気泳動：すべて既報 ${ }^{3,4)}$ に 従った。

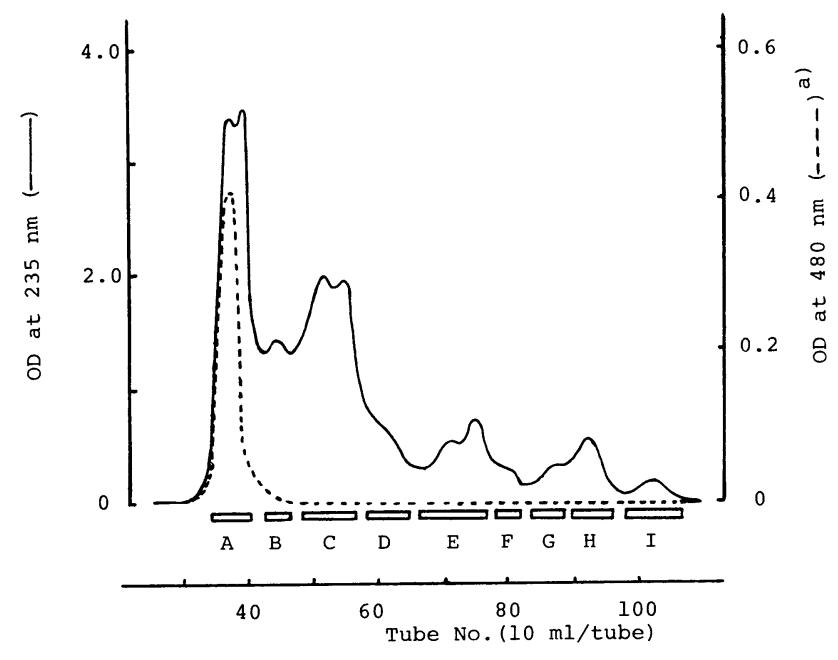

Fig. 1. Gel Filtration of Tryptic Digest of Parotin-Subunit on Sephadex G-25 Column $(3.2 \times 124 \mathrm{~cm})$ Equilibrated with $0.05 \mathrm{M} \mathrm{NH}_{4} \mathrm{HCO}_{3}$

a) One hundred $\mu \ell$ aliquot was taken for sugar determination by phenol- $\mathrm{H}_{2} \mathrm{SO}_{4}$ method. 
Table I. Biological Activity of Tryptic Peptides of Parotin-Subunit

\begin{tabular}{cccc}
\hline \multirow{2}{*}{ Fr. ${ }^{\text {a) }}$} & $\begin{array}{c}\text { Ca decreasing } \\
\text { activity }\left(\frac{8}{6}\right)\end{array}$ & \multicolumn{2}{c}{ Leucocyte activity } \\
\cline { 3 - 4 } & Decreasing & Increasing \\
\hline A & 1.68 & - & + \\
B & 2.85 & - & + \\
C & 0.42 & - & - \\
D & 1.05 & - & + \\
E & 2.38 & - & + \\
F & 1.30 & - & - \\
G & 1.30 & - & - \\
H & 10.32 & - & \\
\hline
\end{tabular}

a) dose; $20 \mu \mathrm{g} / \mathrm{kg}$, i.v.

b) mean of Ca decreasing \% in rabbit serum at 6 or $7 \mathrm{hr}$ after injection

c) variation over $20 \%$ in circulating leucocyte number of rabbit blood at 1, 2, 4, 6 or $8 \mathrm{hr}$ after injection

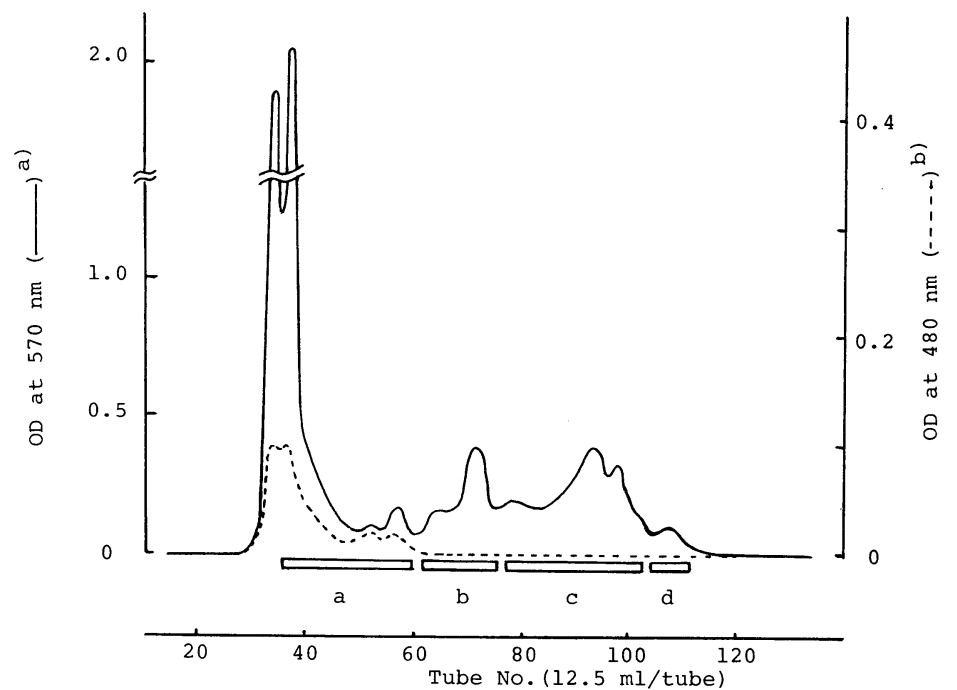

Fig. 2. Gel Filtration of Partial Tryptic Digest of Parotin-Subunit on Sephadex G-75 Column $(3.6 \times 115 \mathrm{~cm})$ Equilibrated with $0 . \angle \mathrm{N}$ Acetic Acid

a) One $\mathrm{ml}$ aliquot was taken for protein determination by ninhydrin reaction.

b) Five hundred $\mu \ell$ aliquot was taken for sugar determination by phenol- $\mathrm{H}_{2} \mathrm{SO}_{4}$ method. 
Table 2. Biological and Immunological Activities of Partial Tryptic Peptides of Parotin-Subunit

\begin{tabular}{ccc}
\hline Fr. $^{\text {a) }}$ & \multicolumn{2}{c}{ Ca decreasing } \\
activity $(\%)$ & $\begin{array}{l}\text { Immunological } \\
\text { activity }\end{array}$ \\
\hline a & 1.38 & 36 \\
b & -0.20 & $<1$ \\
c & -2.00 & $<1$ \\
d & 8.32 & $<1$ \\
\hline
\end{tabular}

a) dose; $20 \mu \mathrm{g} / \mathrm{kg}$, i.v.

b) See Table I.

c) relative activity in weight to weight when activity of parotinsubunit referred as 100 in radioimmunoassay

\section{実 験 結 果}

Trypsin 加水分解物の分画：Fig. 1 に示すようにtrypsin による完全加水分解物を Sephadex G - 25 力

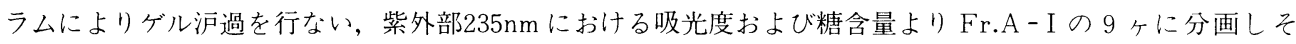
れぞれ凍結乾燥品として回収した. Subunitに含まれる糖はFr.Aにのみ認められ，生物学的効力について

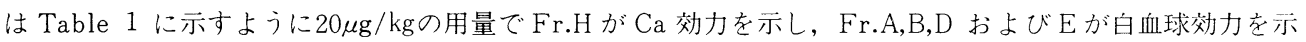
すことを認めた。なお Fr. I はアミノ酸分析の結果 Lys,Arg およびsubunitのC末端アミノ酸である Leu ${ }^{4)}$ を含まず，加水分解による副産物と考えられる。またFig. 2 に示すようにtrypsin の限定分解物を Seph$\operatorname{adex}$ G-75力ラムを用いて分画し, 各分画の radioimmunoassay による免疫活性および Ca 効力を測定し た、その結果をTable 2 に示すように，糖を含むFr.a に免疫活性が, Fr.d に Ca 効力が存在することを 認めた。なおFr.a の前に溶出するピークはポリアクリルアミドゲル電気泳動法により元の subunit である ことを確認している. 以上のことから Ca 効力, 白血球効力および免疫活性が subunit 分子上の異なる部位 に存在することが明らかとなり，以下完全加水分解物中より免疫活性抢よび白血球効力を有する Fr. A と Ca 効力を有寸るFr.Hについて精製を行なった。
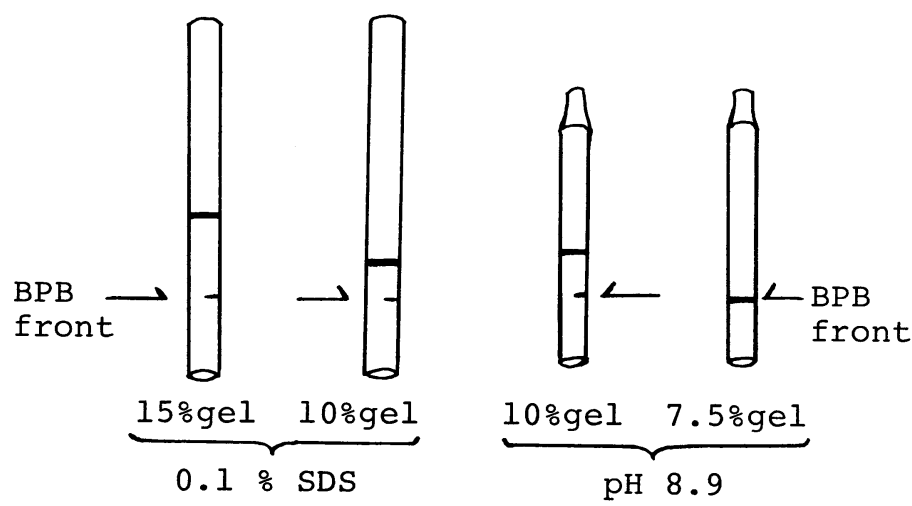

Fig. 3. Polyacrylamide Gel Electrophoretic Pattern of Fr. AA-1 top: cathode staining: Amido Black 10B 
活性フラグメントの分離：Fr.A を Sephadex G-50（2.0×103cm）を用いて分画し糖を含むFr.AA を 得, さらにQAE - Sephadex A-25 (2.0×30cm) を用いて gradient elution を行ない食塩濃度0.3〜0.4 Mで溶出される分画 Fr.AA - 1 を得た.このものはFig. 3 に示すようにポリアクリルアミドゲル電気泳動で 均一な挙動を示した.Fr.AA-1の収量は90.0mgであった.Fr.HについてはFig. 4 に示すようにぺーパー クロマトグラフィーを行ない, Rf=0.4を示す Fr.H-1 を $10 \% \mathrm{CH}_{3} \mathrm{COOH}$ により回収した.収量は $2.1 \mathrm{mg} て ゙$ あった。このように分離したFr.AA- 1 およびFr.H－1 の生物学的効力を検定したところ Table 3 に示

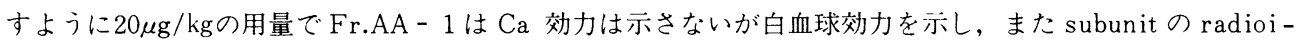
mmunoassay を用いて免疫活性を測定したところ強い活性を有することを認めた. Fr.H - 1 は $20 \mu \mathrm{g} / \mathrm{kg} の$ 用量で12.33\%の Ca 効力を示したが白血球効力は示さなかった。なお Fr.AA - 1 は $20 \mu \mathrm{g} / \mathrm{kg}$ の用量で subunit および Fr.H - 1 と異なり投与後 4 時間目に7.34\%の家鬼血清 Ca 低下作用を示すことを認めた。
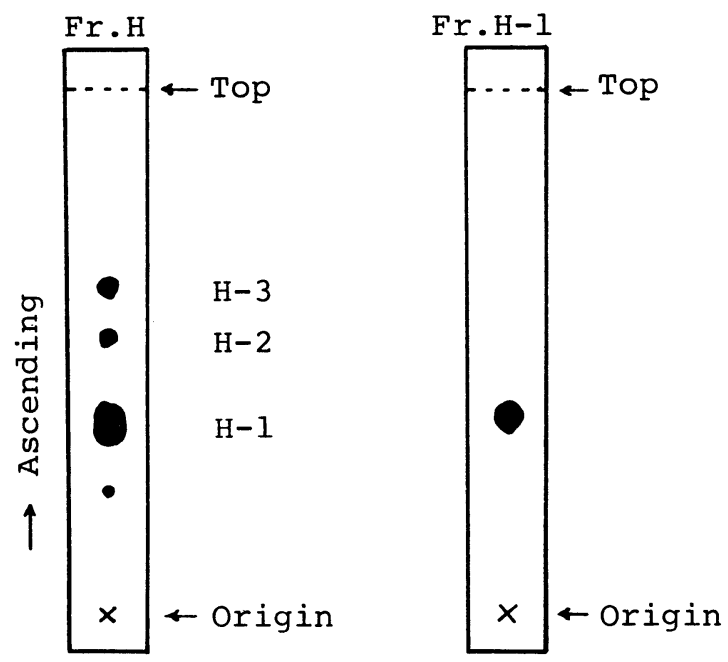

Fig. 4. Paper Chromatogram of Fr.H

paper: Toyo filter paper No. $50(2 \times 40 \mathrm{~cm})$

solvent: n-BuOH: Pyridine: $\mathrm{CH}_{3} \mathrm{COOH}: \mathrm{H}_{2} \mathrm{O}$

(15:10:3:12)

staining: ninhydrin reagent

Table 3. Biological and Immunological Activities of Fr.AA-1 and Fr.H-1

\begin{tabular}{|c|c|c|c|c|}
\hline \multirow{2}{*}{$\mathrm{Fr}^{\mathrm{a})}$} & \multirow{2}{*}{$\begin{array}{l}\text { Ca decreasing } \\
\text { activity }\left(\frac{8}{b}\right)^{b}\end{array}$} & \multicolumn{2}{|c|}{ Leucocyte activity ${ }^{b)}$} & \multirow{2}{*}{$\begin{array}{l}\text { Immunological } \\
\text { activity }\end{array}$} \\
\hline & & Decreasing & Increasing & \\
\hline$A A-1$ & 1.98 & - & + & 1600 \\
\hline $\mathrm{H}-1$ & 12.33 & - & - & $<1$ \\
\hline
\end{tabular}

a) dose; $20 \mu \mathrm{g} / \mathrm{kg}$, i.v.

b) See Table 1 .

c) See Table 2 . 


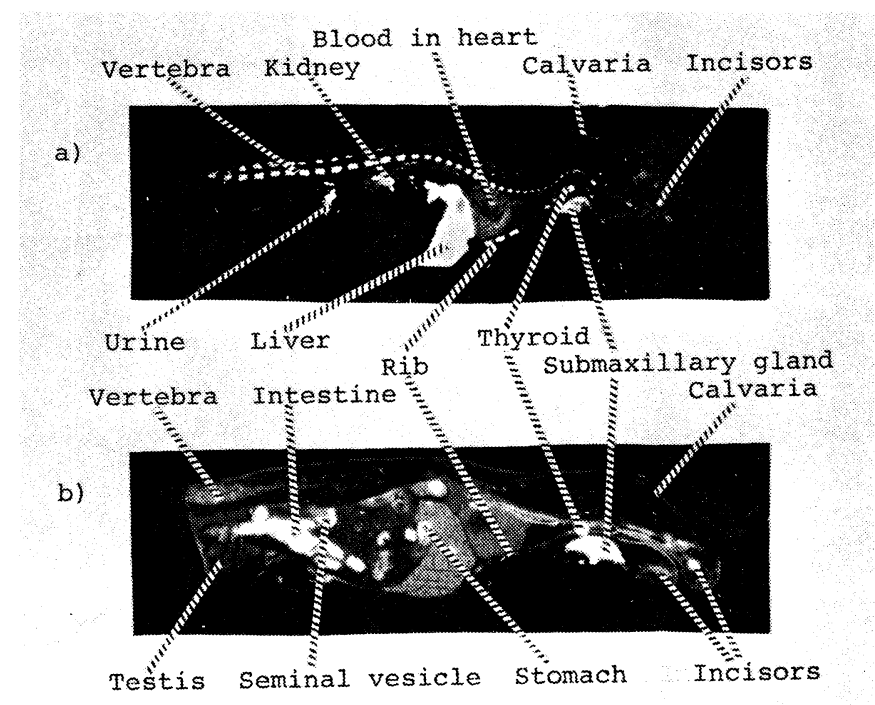

Fig. 5. Whole-Body Autoradiograms of Male Mice Injected with ${ }^{\mathbf{1 3 1}}$ I-ParotinSubunit
a) 20 min after injection
b) 60 min after injection

a)
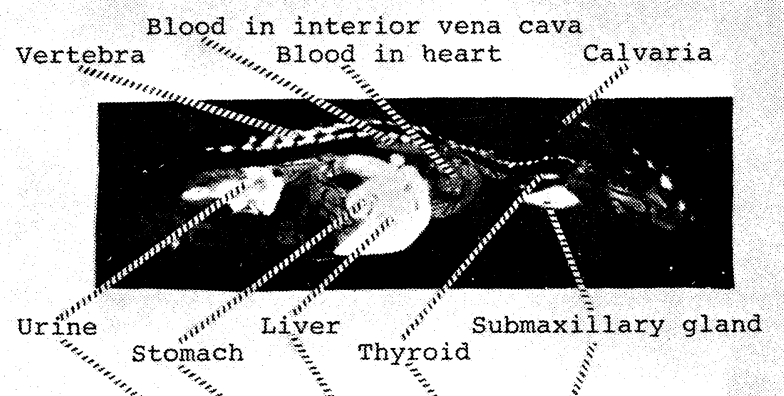

b)

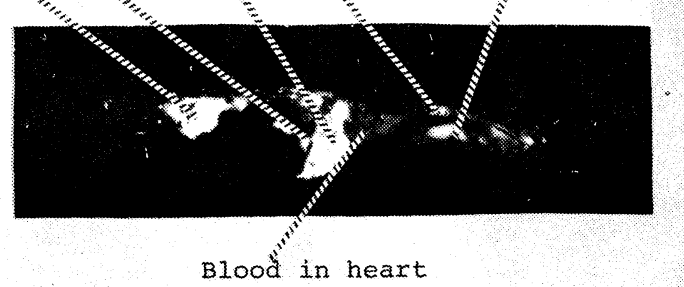

Fig. 6. Whole-Body Autoradiograms of Male Mice $20 \mathrm{~min}$ after Injected with ${ }^{131}$ I-Fr.AA-1 and ${ }^{131}$ I-Fr.H-1

a) ${ }^{131}$ I-Fr.AA-1

b) ${ }^{131} \mathrm{I}-\mathrm{Fr} . \mathrm{H}-1$ 


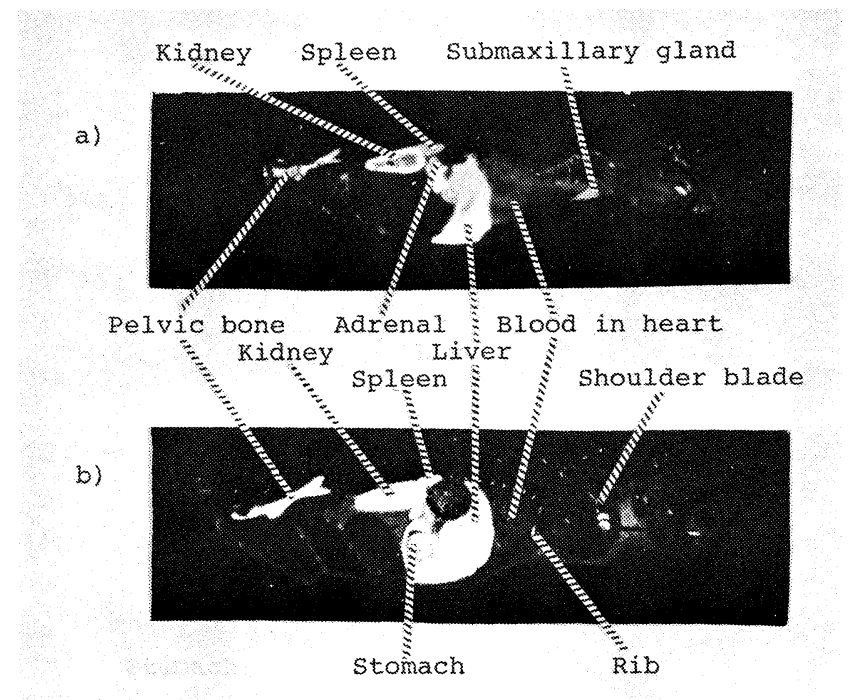

Fig. 7. Whole-Body Autoradiograms Showing the Specific Localization in Pelvic Bone of Male Mice 20 min after Injected with ${ }^{131}$ I-ParotinSubunit and ${ }^{131}$ I-Fr.AA-1

a) ${ }^{131}$ I-Parotin-Subunit

b) ${ }^{131}$ I-Fr.AA-1

Table 4. Localization of ${ }^{131} \mathrm{I}-$ Subunit, ${ }^{131} \mathrm{I}-\mathrm{Fr} . \mathrm{AA}-1,{ }^{131} \mathrm{I}-\mathrm{Fr} . \mathrm{H}-1$ and Radio-Iodine in Mouse by Whole-Body Autoradiography

\begin{tabular}{|c|c|c|c|c|c|c|c|c|}
\hline \multirow{3}{*}{ Tissue } & \multicolumn{8}{|c|}{ Relative degree of localization ${ }^{a}$ ) } \\
\hline & \multicolumn{2}{|c|}{$\overline{131}$ I-Subunit } & \multicolumn{2}{|c|}{$131_{\text {I-Fr.AA-I }}$} & \multirow{2}{*}{\multicolumn{2}{|c|}{${ }_{20}^{131}$ I-Fr. 60}} & \multicolumn{2}{|c|}{ Radio-Iodine } \\
\hline & 20 & 60 & 20 & 60 & & & & $60(\mathrm{~min})$ \\
\hline Bone & + & \pm & + & + & - & - & - & - \\
\hline Incisors & + & + & + & \pm & - & - & - & - \\
\hline Liver & + & \pm & + & + & + & + & - & - \\
\hline Spleen, Adrenal & + & - & + & \pm & + & - & + & - \\
\hline Thyroid, Kidney, stomach & + & + & + & + & + & + & + & + \\
\hline Submaxillay gland, Urine & + & + & \pm & + & + & + & + & + \\
\hline
\end{tabular}

a) shown as follows:- lower than blood, tequal to blood, + higher than blood

全身オートラジオグラフィー：まず ${ }^{13} 11$ I - Subunit のマウス正中断面における全身オートラジオグラムを Fig. 5 に示すが，投与後20分において椎骨，肋骨，頭蓋冠などの骨組織，肝臓，甲状腺および顎下腺などの 組織に血中濃度よりも高い放射活性の分布を認め, 次いで尿および唾液に血中濃度と同程度の放射活性の分 布を認めた。投与後 60 分においては, 甲状腺, 胃, 尿および唾液に血中濃度よりも高い放射活性の分布を認 め, 次いで骨組織, 肝臓および睪丸に血中濃度と同程度の放射活性の分布を認めた。なお雌性マウスにおい ても生殖器をのぞき雄と同様の結果を得た. Fig. 6 に ${ }^{131} \mathrm{I}-$ Fr.AA - 1 および ${ }^{131} \mathrm{I}-$ Fr.H - 1 の投与後 20 分 における正中断面の全身オートラジオグラムを示すが, ${ }^{131}$ I - Fr.AA - 1 につては, ${ }^{131} I$ - Subunit と同様に 骨組織および肝臓などの組織に血中濃度よりも高い放射活性の分布を認め, 次いで顎下腺および尿に血中濃 度と同程度の放射活性の分布を認めた。なお投与後60分においても生殖器をのぞき ${ }^{131} \mathrm{I}-\mathrm{Subunit}$ と同様の 結果を得ている。しかし ${ }^{131} I-F r . H － 1$ については，肝臓，甲状腺および顎下腺などに放射活性の分布を認 
めたが骨組織への分布は認められなかった．Fig. 7 に左側面の全身オートラジオグラムを示すが，投与後20 分において ${ }^{131}$ I - Subunit および ${ }^{131}$ I - Fr.AA - 1 ともに骨盤, 腎臓, 脾臓, 歯髄および副腎に血中濃度よ りも高い放射活性の分布を認めた，以上の結果を Table 4 にまとめ， Na ${ }^{131} \mathrm{I}$ の放射活性の分布と比較する と，骨組織，肝臓および歯䯣に ${ }^{131}$ I - Subunit および131I - Fr.AA - 1が特異的に分布することを認めた。

Table 5. Amino Acid Compositions of Fr.AA-1 and Fr.H-1

\begin{tabular}{ccc}
\hline & Fr.AA-1 & Fr.H-1 \\
\cline { 2 - 3 } amino acid & $\begin{array}{c}\text { residues/mole } \\
\text { (nearest integral/mole) }\end{array}$ & $\begin{array}{c}\text { residues/mole } \\
\text { (nearest integral/mole) }\end{array}$ \\
\hline Asp & $8.81(9)$ & $0.81(1)$ \\
Thr & $2.80(3)$ & \\
Ser & $2.02(2)$ & $1.06(1)$ \\
Glu & $11.58(12)$ & \\
Gly & $1.75(2)$ & \\
Ala & $2.97(3)$ & \\
Val & $2.55(3)$ & $1.02(1)$ \\
Met & $1.00(1)$ & \\
Ile & $3.38(3)$ & \\
Leu & $6.60(7)$ & \\
Tyr & $2.30(2)$ & \\
Phe & $1.69(2)$ & $1.00(1)$ \\
Lys & $3.97(4)$ & \\
His & $0.36(0)$ & \\
Arga) & $2.36(2)$ & \\
Trp & $2.09(2)$ & \\
\hline
\end{tabular}

a) by ultraviolet absorption method

Table 6. Sequential Degradations of Fr.AA-1 and Fr.H-1

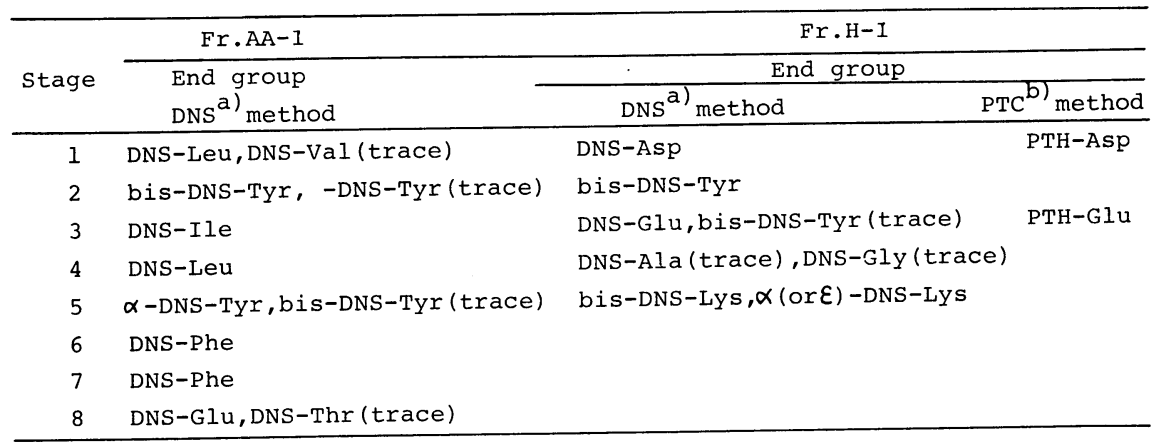

a) DNS; dansyl

b) PTC; phenylisothiocyanate, identified as phenylthiohydantoin amino acid

Table 7. Molecular Weight and Sugar Component of Fr.AA-1

\begin{tabular}{|c|c|c|}
\hline Molecular weight & $\begin{array}{l}\text { by } 15 \% \text { polyacrylamide gel } \\
\text { electrophoresis in } 0.1 \% \mathrm{SDS}^{\mathrm{a}} \text { ) }\end{array}$ & 9100 \\
\hline \multirow[t]{2}{*}{ Sugar component } & $\begin{array}{l}\text { uronic acid } \\
\text { (as glucuronic acid) }\end{array}$ & 7.48 \\
\hline & $\begin{array}{l}\text { amino sugar } \\
\text { (as glucosamine) }\end{array}$ & $6.9 \%$ \\
\hline
\end{tabular}

a) sodium dodecyl sulfate 


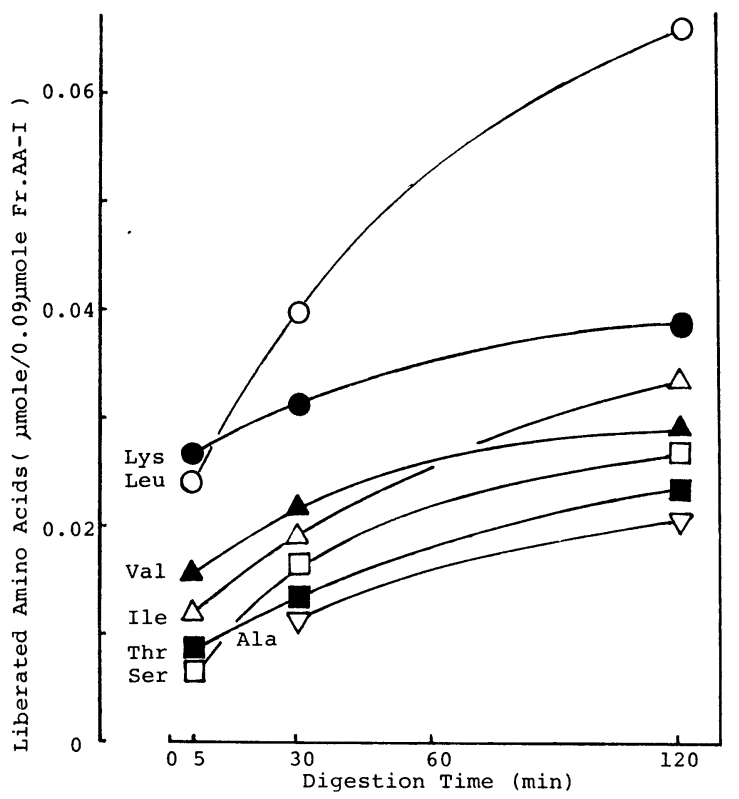

Fig. 8. Time Course of Amino Acids Liberated from Fr.AA-1 by Carboxypeptidase A and B

Fr.AA - |および Fr.H - |のアミノ酸配列分析, 糖含量および分子量: Table 5 にアミノ酸組成を示 すが, Fr.AA - 1 は subunit と同様に Glu,Asp,Leuの含量が多く,Fr.H- 1 は Glu,Asp,Tyr,Trp および Lys の各々 1 分子から成ることを認めた。各フラグメントにつきdansyl-Edman法により N末端アミノ酸配 列分析を行なったところ, Table 6 に示すようにFr.AA- 1 の N 末端アミノ酸配列はLeu-Tyr-Ile-LeuTyr-Phe-Phe-Glx-であり，またFr.H－１はN来端よりAsp-Tyr-Gluーとなり，4番目はアミノ酸組成 の結果とも考えあわせTrp, 5 番目はLys と決定した。Fr.AA－ 1 のC末端アミノ酸配列分析の結果をFig. 8 に示すが, carboxypeptidase A およびBにより遊離してくるアミノ酸を定量した結果 -Ile-Val-LeuLeu-Lys（OH）であることを認めた。なおFr.AA- 1 およびFr.H－1 ともにC末端アミノ酸はLys で あり trypsin 加水分解物として適当であった. Table 7 に示すようにFr.AA- 1 の分子量はSDS-ゲル電

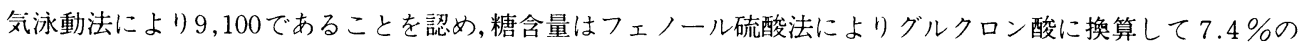
ウロン酸, また $4 \mathrm{~N} \mathrm{HCl}$ 中, $100^{\circ} \mathrm{C}, 6$ 時間の加水分解物について $\mathrm{Blix}$ 変法によりグルコサミンに換算して

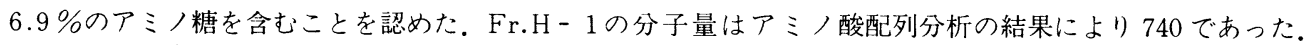
なお DCC 法 ${ }^{15)} に よ り$ 合成したFr.H－1のN末端ジペプチドAsp-Tyr (OH）およびFr.H - 1 の構成アミ ノ酸につきそれぞれ生物学的検定を行なったが, $20 \mu \mathrm{g} / \mathrm{kg}$ の用量ではいずれも効力を示さなかった。

\section{考 察}

近年ホルモンの化学構造研究の進歩にともない, ガストリン ${ }^{7)}, \mathrm{ACTH}^{10)}$, 成長ホルモン ${ }^{5)}$ な゙において 生理作用発現には全構造を必要とせず，いわゆる活性フラグメントが存在することが知られている．著者ら も subunit からより低分子の活性フラグメントを得る目的で trypsin 加水分解を行なったところ活性は失な われず，しかも subunit 分子上で $\mathrm{Ca}$ 効力，白血球効力および免疫活性が分散していることを明らかにする 
とともに活性フラグメントの分離に成功した．Ca 効力を有する Fr.H - 1 はAsp-Tyr-Glu-Trp-Lys ( OH) のペンタペプチドで，Ca 代謝に影響をおよぼす他の蛋白性ホルモンのアミノ酸配列と類似性はみられず新 しい物質であった．また subunit と免疫化学的に交叉反応を示し白血球効力を有する Fr.AA- 1 は分子量 9,100 の糖ペプチドで14.3\%の糖含量を示し, 分子量 45,000 の subunit が3.3\%の糖を含むことから ${ }^{4)}$ subu nit 中の糖がすべてこのFr.AA－1に局在するものと思われる。Fr.AA - 1 のN末端は Leu, C 末端は Lys でまたFr.H－1のN末端はAsp，C末端はLys で，すでに報告した subunit の NおよびC 末端はそれぞ れ Gly,Leu であり ${ }^{3,4)}$ ，今回得た活性フラグメントFr.AA-1およびFr.H - 1 はいずれも subunitの末端 部に位置しないことを認めた. Subunit および活性フラグメントFr.AA- 1,Fr.H - 1 の作用拉よび代謝を 比較検討する目的でマウスにおける全身オートラジオグラフィーを行なったところ, 骨における cyclic A MP-adenyl cyclase系拐よびCa 代謝に影響をおよぼす subunit は ${ }^{3,4)}$, 骨組織㧍よび歯髄に高い分布を示 し, $\mathrm{Na}{ }^{131}$ あるいは成長ホルモン ${ }^{13)}$ ）カルシトニン ${ }^{9)}$, 副甲状腺ホルモン ${ }^{111}$ などとは異なる特異性を有する ことを認めたが, subunit と同様の Ca 効力を示す Fr.H - 1 は骨組織に分布しなかった。一方 Ca 効力を示 さないFr.AA－1が subunit と同様骨組織に分布することが認められた。すでに parotin あるいは subun it などの唾液腺ホルモン関連物質の体内分布実験により ${ }^{1)}$, 肝臟抢よび腎臓に高い放射能の分布が報告され ているが, 今回の全身オートラジオグラフィーにより単なる体内分布実験では検出されなかった骨組織およ び歯髄において高い分布を認め, 唾液腺ホルモン研究の初期より明らかにされてきた骨に対する作用を裏付 ける極めて興味ある結果を得たものと考える。

\section{結 論}

1) Subunit の trypsin 加水分解物中より, subunit との免疫化学的交叉性と家兔循環白血球数增加効力を 示す Fr.AA－１および家鬼血清 Ca 低下効力を示す Fr.H - 1 の 2 種の活性フラグメントを分離することに 成功した。

2）Fr.AA－ 1 は分子量9,100の糖ペプチドであり $\mathrm{N}$ 末端アミノ酸配列は Leu-Tyr- Ile-Leu-Tyr-PhePhe-Glx-, C 末端アミノ酸配列は-Ile-Val-Leu-Leu-Lys $(\mathrm{OH})$ であった. 糖組成は $7.4 \%$ のウロン酸およ

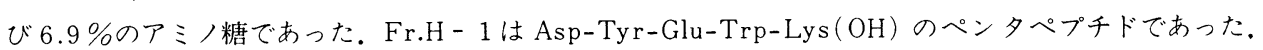

3） ${ }^{131}$ I - Subunit および131I - Fr.AA - 1 は，マウスにおける全身オートラジオグラフィーにおいて骨組織 に特異的に分布することを認めたが, ${ }^{13} 1$ I - Fr.H - 1 は骨組織に分布しないことを認めた。

謝辞＼cjkstart最後に実験材料の一部を提供された帝国臟器製薬株式会社に心から感謝する。

\section{文献}

1) 青沼 繁, 三村 務：I ${ }^{131}$ 標識パロチンの研究, 生化学, 32: 528-560, 1960.

2) 青沼 繁, 小浜皘弘: 顎下腺の研究 (第14報) パロチンの Radioimmunoassay, 薬学雑誌, 92: 828 -835, 1972. 3) 青沼 繁, 小浜竱弘, 中陳静男, 屋敷伸治, 江川 宏：唾液腺ホルモンの Subunitに関する生理化学的研究, 日内分泌会誌, 50: 1468-1476, 1974.

4) 青沼 繁, 小浜 靖弘, 中陳静男, 屋敷伸治, 江川 宏, 和田昌師, 小宮山豊：唾液腺ホルモンの Subunitに関する生理化 学的研究 (その 2), 日内分泌会誌, 52: 93-104, $1976 . \quad 5)$ Gráf, L. and Li, C.H.: Isolation and properties of two biologically active fragments from limited tryptic hydrolysis of bovine and ovine pituitary growth hormone, Biochemistry, 13: 5408-5415, 1974.

6) Gray, W.R.: Methods in Enzymology XI, Academic Press, New York, 1976, P. 469 475.

7) Gregory, R.A.: The isolation and chemistry of gastrin, Gastroenterology, 51: 953-959, 
1966. 8) Hartley, B.S.: Strategy and tactics in protein chemistry, Biochem. J., 119: 805-822, $1970 . \quad$ 9) Hicks, E.P., Cooper, C.W. and Waddell, W.J.: Whole-body autoradiography of the distribution of ${ }^{125}$ I-Thyrocalcitonin in mice, J. Dent. Res., 50: 1307 -1313, $1971 . \quad 10)$ Hofmann, K., Yajima, H., Yanaihara, N., Liu, T. and Lande, S.: Studies on polypeptide XIII The synthesis of a tricopeptide possessing essentially the full biological activity of natural ACTH, J. Amer. Chem. Soc., 83: 487-489, 1961.

11) de Kretser, D.M., Martin, J.J. and Melick, R.A.: The radioautographic localization of ${ }^{125}$ I-labeled bovine parathyroid hormone, J. Endocr., 46: 507-510, 1970.

12) Maghuin-Rogister, G. Closset, J. and Hennen, G.: The carboxy-terminal primary structure of the $\beta$-Subunit from bovine and porcine lutenizing hormone, FEBS lett., 13: $301-$ 305, $1971 . \quad$ 13) Mayberry, H.E., Van den Brand, J.L., Van Wyk, J.J. and Waddell, W.J.: Early localization of ${ }^{125}$ I-labeled human growth hormone in adrenal and other organs of immature hypophysectomized rats, Endocrinology, 88: 1309-1317, 1971.

14) Schroeder, W.A.,: Methods in Enzymology XI, Academic Press, New York, 1967, P. $445 \sim 461$.

15) Sheehan, J.C. and Hess, G.P.: New method of forming peptide bonds, J. Amer. Chem. Soc., 77: 1067-1068, 1955. 